\title{
Pengaruh Strategi Pembelajaran ARCS Terhadap Hasil Belajar Fisika Ditinjau Dari Motivasi Belajar Peserta Didik Kelas XI MIA SMA Negeri 1 Malunda
}

\author{
Sutrisno \\ Universitas Sulawesi Barat \\ sutrisno@unsulbar.ac.id
}

\begin{abstract}
This research is a true experimental study using a $2 \times 2$ factorial design carried out in class XI MIA2 and XI MIA3 senior high school 1 Malunda, Majene Regency. Data collection in this study was carried out in three stages, namely; 1) the preparation stage, 2) the implementation stage, 3) the final stage by giving a final test of physics learning outcomes which is then analyzed to test the hypothesis. The results of hypothesis testing were carried out with a two-way analysis of variance which showed that (1) there were differences in physics learning outcomes between students who were taught through ARCS learning strategies and those taught using conventional learning, (2) for high learning motivation, there were differences between the results. learning physics students who are taught using ARCS learning strategies with students taught with conventional learning, (3) for low learning motivation, there is a difference between the physics learning outcomes of students taught using ARCS learning strategies with students taught using conventional learning, and (4) there is an interaction effect between learning strategies and learning motivation on the achievement of physics learning outcomes, in class XI MIA students of senior high school 1 Malunda.
\end{abstract}

Keywords: ARCS Learning Strategy, Learning Motivation, Physics Learning Outcomes, True Experiment, And Factorial Design.

Abstrak. Penelitian ini merupakan penelitian true eksperiment menggunakan desain faktorial $2 \times 2$ yang dilaksanakan di kelas XI MIA2 dan XI MIA 3 SMAN 1 Malunda Kab. Majene. Pengumpulan data dalam penelitian ini dilaksanakan dalam tiga tahap yaitu; 1) tahap persiapan, 2) tahap pelaksanaan, 3) tahap akhir dengan pemberian tes akhir hasil belajar fisika yang kemudian dilakukan analisis untuk uji hipotesis. Hasil pengujian hipotesis yang dilakukan dengan analisis varians dua arah yang menunjukkan bahwa (1) terdapat perbedaan hasil belajar fisika yang atara siswa yang diajar melalui strategi pembelajaran ARCS dan yang diajar dengan mengunakan pembelajaran konvensional, (2) untuk motivasi belajar tinggi, terdapat perbedaan antara hasil belajar fisika siswa yang diajar dengan menggunakan strategi pembelajaran ARCS dengan siswa yang diajar dengan pembelajaran konvensional, (3) untuk motivasi belajar rendah, terdapat perbedaan antara hasil belajar fisika siswa yang diajar dengan menggunakan strategi pembelajaran ARCS dengan siswa yang diajar dengan pembelajaran konvensional, dan (4) terdapat pengaruh interaksi antara strategi pembelajaran dan motivasi belajar pada pencapaiaan hasil belajar fisika, pada peserta didik kelas XI MIA SMAN 1 Malunda.

Kata Kunci: Strategi Pembelajaran ARCS, Motivasi Belajar,Hasil belajar fisika, true eksperiment, Desain factorial

\section{PENDAHULUAN}

Pendidikan merupakan sebuah proses mengubah kemandirian, kesadaran akan tanggung jawab, dan kewajiban dalam hidup manusia. Merubah kemandirian dan kesadaran akan tanggung jawab harus melalui proses yang lama, karena pengetahuan dan pengalaman yang baik dan bermakna dalam pendidikan tidaklah diperoleh manusia begitu saja, tetapi melalui proses belajar. Proses belajar dalam pelaksanaannya harus sesuai dengan tujuan umum dari belajar itu sendiri, yaitu mendapat pengetahuan, pemahaman konsep dan keterampilan, serta pembentukan sikap. Sejalan dengan pentingnya pelaksanaan pendidikan dan pembelajaran berdasarkan tujuan, maka 
pelaksanaan pembelajaran dan pendidikan ilmu pengetahuan alam harus memperhatikan faktorfaktor yang berpengaruh.

Faktor mempengaruhi hasil belajar salah satunya adalah peranan seorang pendidik. Seorang guru harus memberikan pendekatan atau strategi yang dapat membantu siswa mencerna konsep dalam pembelajaran sains, artinya pendekatan yang digunakan pada pembelajaran sains khususnya Fisika harus dapat menuntut siswa untuk berkonsentrasi.

Keberadaan motivasi dalam pembelajaran sangat penting karena merupakan kondisi psikologi berupa dorongan atau usahausaha untuk melaksanakan kegiatan belajar sehingga ada partisipasi siswa dalam kegiatan pembelajaran. Salah satu indikator keberhasilan pendidikan secara mikro ditataran pembelajaran kelas adalah apabila seorang guru mampu membangun motivasi belajar para siswanya.

Berdasarkan hal diatas, maka dibutuhkan suatu pembelajaran dengan menggunakan pendekatan kontekstual, yaitu pendekatan yang membangun motivasi belajar siswa dengan mengaitkan antara materi pelajaran dan konteks relevan. Langkah untuk memotivasi menggunakan empat kondisi motivasi, yaitu strategi motivasi yang dikembangkan oleh Jhon Keller dikenal dengan strategi pembelajaran ARCS (Attention, Relevance, Confidence, Satisfaction). Maka penulis tertarik untuk mengkaji lebih jauh tentang strategi pembelajaran dengan memperhatikan motivasi belajar, sebagai sebuah inovasi dalam pengembangan pembelajaran melalui suatu kajian penelitian "Pengaruh Strategi Pembelajaran Attention, Relevance, Confidence, and Satisfaction (ARCS) terhadap hasil belajar ditinjau dari motivasi belajar peserta didik Kelas XI MIA SMA Negeri 1 Malunda".

\section{METODE}

Penelitian ini merupakan penelitian true eksperiment menggunakan desain penelitian faktorial $2 \times 2$. seperti pada Tabel berikut:
Tabel 1. Rancangan Penelitian

\begin{tabular}{|c|c|c|}
\hline Motivasi belajar (B) & $\begin{array}{l}\text { Strategi Pembelajaran ARCS } \\
\qquad\left(A_{1}\right)\end{array}$ & $\begin{array}{l}\text { Pembelajaran langsung } \\
\qquad\left(\mathrm{A}_{2}\right)\end{array}$ \\
\hline $\begin{array}{l}\text { Motivasi belajar tinggi } \\
\left(\mathrm{B}_{1}\right)\end{array}$ & $\mathrm{Y}\left[\mathrm{A}_{\mathrm{l}} \mathrm{B}_{\mathrm{l}}\right]$ & $\mathrm{Y}\left[\mathrm{A}_{2} \mathrm{~B}_{\mathrm{l}}\right]$ \\
\hline $\begin{array}{l}\text { Motivasi belajar rendah } \\
\qquad\left(\mathrm{B}_{2}\right)\end{array}$ & $\mathrm{Y}\left[\mathrm{A}_{1} \mathrm{~B}_{2}\right]$ & $\mathrm{Y}\left[\mathrm{A}_{2} \mathrm{~B}_{2}\right]$ \\
\hline$\Sigma$ & $\mathrm{Y}\left[\mathrm{A}_{1} \mathrm{~B}_{1}\right]+\mathrm{Y}\left[\mathrm{A}_{1} \mathrm{~B}_{2}\right]$ & $\mathrm{Y}\left[\mathrm{A}_{2} \mathrm{~B}_{1}\right]+\mathrm{Y}\left[\mathrm{A}_{2} \mathrm{~B}_{2}\right]$ \\
\hline
\end{tabular}

(Adaptasi dari Emzir, 2007: 103)

Sampel penelitian ini diambil 2 dari 3 kelas XI MIA SMAN 1 Malunda tahun ajaran 2016/2017 melalui simple random sampling (secara rambang sederhana).

\section{KAJIAN TEORI \\ Hasil Beljar Fisika}

Hasil belajar ranah kognitif diperoleh dari hasil tes untuk mengukur tingkat pencapaian setelah suatu materi pembelajaran diberikan. Anderson \& Krathwohl (2001), dimensi kognitif memaparkan tentang apa yang peserta didik ketahui (pengetahuan) dan bagaimana proses berpikirnya (proses kognitif). Kategori-kategori dalam dimensi proses kogitif secara mendetail dibagi menjadi enam ranah $\mathrm{C}_{1}, \mathrm{C}_{2}, \mathrm{C}_{3}, \mathrm{C}_{4}, \mathrm{C}_{5}$, dan $\mathrm{C}_{6}$.

Berdasarkan beberapa pendapat diatas dapat disimpulkan bahwa hasil belajar fisika ranah kognitif adalah hasil yang dicapai oleh peserta didik setelah mengikuti proses belajar fisika dalam kurun waktu tertentu berdasarkan kategori dalam dimensi proses kogitif yang terdiri dari enam ranah $\mathrm{C}_{1}, \mathrm{C}_{2}, \mathrm{C}_{3}, \mathrm{C}_{4}, \mathrm{C}_{5}$, dan $\mathrm{C}_{6}$ yang diperoleh dari hasil pengukuran melalui suatu alat ukur yaitu tes.

\section{Strategi Pembelajaran ARCS}

Strategi pembelajaran ARCS (Attention, Relevance, Confidence, Satisfaction), dikembangkan oleh Keller sebagai jawaban dari pertanyaan bagaimana merancang pembelajaran yang mempengaruhi motivasi berprestasi dan hasil belajar siswa. Strategi pembelajaran ini dikembangkan berdasarkan teori nilai harapan (expectancy value theory) serta mengandung dua komponen yaitu nilai (value) dari tujuan yang akan dicapai dan harapan (expectancy) agar berhasil mencapai tujuan itu. Dari dua komponen tersebut Keller mengembangkannya menjadi empat komponen (Norhasimi, 2012). Proses 
pembelajaran strategi pembelajaran ARCS meliputi empat fase lebih jelasnya dapat terlihat seperti pada Gambar 1. berikut ini :

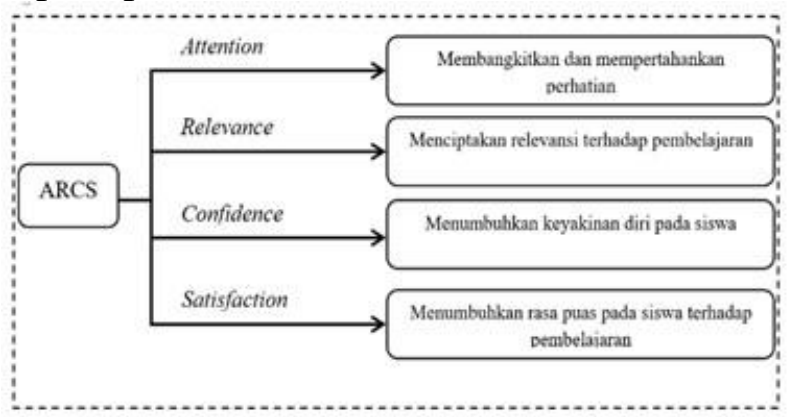

Gambar 1. Strategi ARCS

Sumber : (Wena, 2010: 36)

\section{Pembelajaran Langsung}

Pembelajaran langsung adalah salah satu pendekatan mengajar yang dirancang khusus untuk menunjang proses belajar peserta didik yang berkaitan dengan pengetahuan deklaratif dan pengetahuan prosedural yang terstruktur dengan baik yang dapat diajarkan dengan pola kegiatan yang bertahap, selangkah demi selangkah.

Berdasarkan pendapat tersebut, penulis dapat simpulkan bahwa dalam pembelajaran langsung merupakan pembelajaran yang menekankan pentingnya membantu peserta didik memahami komponen-komponen suatu disiplin disiplin ilmu. Memperhatikan pola pembelajaran yang selama ini diterapkan oleh guru Fisika di sekolah XI MIA SMA Negeri 1 Malunda.

\section{Motivasi Belajar Fisika}

Menurut Uno (2008) indikator motivasi belajar dapat diklasifikasikan sebagai berikut: (1) adanya hasrat dan keinginan berhasil; (2) adanya dorongan dan kebutuhan dalam belajar; (3) adanya harapan dan cita-cita masa depan; (4) adanya penghargaan dalam belajar; (5) adanya kegiatan yang menarik dalam belajar; (6) adanya lingkungan belajar yang kondusif.

Berdasarkan beberapa pendapat diatas, maka dapat ditarik kesimpulan motivasi belajar fisika yaitu perubahan tingkah laku pada setiap individu sebagai pendorong perubahan energi yang dimiliki untuk memenuhi kebutuhan dari dalam dirinya ataupun yang datang dari luar dalam proses berlangsungnya belajar mengajar fisika. Dengan adanya motivasi belajarakan meningkatkan proses belajarnya, sehingga mendapatkan manfaat belajar yang diniatkan dari kegiatan tersebut. serta indikator motivasi belajar adalah (1) adanya keinginan untuk berhasil; (2) adanya dorongan dan kebutuhan dalam belajar; (3) adanya harapan dan cita-cita masa depan; (4) adanya penghargaan dalam belajar;(5) adanya kegiatan yang menarik dalam belajar 6) adanya lingkungan belajar yang kondusif.

\section{Model Pembelajaran Siklus Belajar 5E ditinjau dari Motivasi Belajar Terhadap Hasil Belajar Fisika}

Adanya motivasi yang tinggi dari siswa diharapkan mampu menggerakkan minat siswa untuk menjadikan sekolah bukan hanya sebagai tuntutan namun juga merupakan kebutuhan bagi dirinya. Menurut Sardiman (2008) dalam belajar diperlukan adanyan motivasi. Hasil belajar akan menjadi optimal apabila didukung oleh motivasi. Makin tepat motivasi yang diberikan, maka makin berhasil pula pelajaran itu. Jadi dapat dikatakan bahwa motivasi akan senantiasa menetukan intensitas usaha belajar bagi para peserta didik sehingga hasil belajar yang dicapai akan semakin meningkat (Retno, 2014).

Peserta didik yang memiliki motivasi belajar tinggi cenderung untuk aktif dalam proses pembelajaran terlebih jika menggunakan strategi pembelajaran ARCS. Strategi pembelajaran ARCS merupakan suatu bentuk pendekatan pemecahan masalah untuk merancang aspek motivasi serta lingkungan belajar dalam mendorong dan mempertahankan motivasi siswa untuk belajar (Keller, 1987). Strategi pembelajaran ini berkaitan erat dengan motivasi siswa terutama motivasi untuk memperoleh pengetahuan yang baru.

\section{HASIL DAN PEMBAHASAN \\ Uji Hipotesis \\ Uji Anava Dua Jalur Sel Sama}

Rangkuman hasil uji analisis variansi (ANAVA) dapat ditunjukan pada tabel berikut: Tabel 2 : Rangkuman hasil uji analisis variansi (ANAVA)

\begin{tabular}{|c|c|c|c|c|c|c|}
\hline $\begin{array}{l}\text { Sumber } \\
\text { Varians } \\
\end{array}$ & JK & Dk & $\begin{array}{c}\text { RJK } \\
\left(\mathrm{s}^{2}\right)\end{array}$ & $F_{*}$ & $\begin{array}{c}F_{1} \\
0,05\end{array}$ & Keputusan \\
\hline Antar kelompok (A) & 212,3 & 3 & 70.77 & 21 & 2,87 & $\mathrm{H}_{0}$ ditolak \\
\hline Dalam kelompok (D) & 121.2 & 36 & 3.37 & - & - & \\
\hline Antar kolom (ak) & 52,9 & 1 & 52.9 & 15,69 & 4,11 & $\mathrm{H}_{0}$ ditolak \\
\hline Antar baris (Ab) & 136,9 & 1 & 136,9 & 40,62 & 4,11 & $\mathrm{H}_{0}$ ditolak \\
\hline Interaksi (I) & 22,5 & 1 & 22.5 & 6,67 & 4.11 & $\mathrm{H}_{0}$ ditolak \\
\hline Total direduksi (TR) & 5547,3 & 39 & 142,24 & & & \\
\hline Rerata/Korcksi (R) & 1808,7 & 1 & 1808,7 & & & \\
\hline Total & 545.8 & 42 & & & & \\
\hline
\end{tabular}


1) Perbedaan antara hasil belajar fisika peserta didik yang diajar dengan menggunakan strategi pembelajaran ARCS dengan peserta didik yang diajar menggunakan pembelajaran langsung pada kelas XI MIA SMAN 1 Malunda.

Dari pengujian hipotesis pertama berdasarkan analisis ANAVA menunjukkan $F_{\text {hitung }}=21$ dan $F_{\text {tabel }}=2,87\left(F_{\text {hitung }}>F_{\text {tabel }}\right)$ sehingga dapat disimpulkan $\mathrm{H}_{0}$ ditolak atau dengan kata lain $\mathrm{H}_{1}$ diterima. Artinya, terdapat perbedaan hasil belajar Fisika antara peserta didik yang diajar dengan menggunakan strategi pembelajaran ARCS dan pembelajaran langsung pada peserta didik kelas XI MIA SMAN 1 Malunda.

2) Perbedaan antara hasil belajar fisika peserta didik yang diajar dengan menggunakan strategi pembelajaran ARCS dengan peserta didik yang diajar dengan pembelajaran langsung pada kelas XI MIA SMAN 1 Malunda pada siswa yang memiliki motivasi belajar tinggi

Dari pengujian hipotesis kedua berdasarkan motivasi belajar, menunjukkan $F_{\text {hitung }}=15,69$ dan $F_{\text {tabel }}=4,11\left(F_{\text {hitung }}>F_{\text {table }}\right)$ sehingga $\mathrm{H}_{0}$ ditolak. Hal ini secara tidak langsung telah menjawab hipotesis kedua yakni, untuk motivasi belajar tinggi, terdapat perbedaan antara hasil belajar fisika peserta didik yang diajar dengan menggunakan strategi pembelajaran ARCS dengan peserta didik yang diajar dengan pembelajaran langsung.

3) Perbedaan antara hasil belajar fisika peserta didik yang diajar dengan menggunakan strategi pembelajaran ARCS dengan peserta didik yang diajar dengan pembelajaran langsung pada kelas XI MIA SMAN 1 Malunda pada siswa yang memiliki motivasi belajar rendah.

Berdasarkan hasil analisis hipotesis ketiga diperoleh $F_{\text {hitung }}=40,62$ dan $F_{\text {tabel }}=$ 4,11 ( $\left.\mathrm{F}_{\text {hitung }}>\mathrm{F}_{\text {table }}\right)$ sehingga $\mathrm{H}_{0}$ ditolak dan dapat dijelaskan bahwa pada kelompok peserta didik yang mempunyai motivasi rendah terdapat perbedaan antara hasil belajar fisika peserta didik yang diajar dengan menggunakan strategi pembelajaran
ARCS dengan peserta didik yang diajar dengan pembelajaran langsung.

4) Pengaruh interaksi antara strategi pembelajaran dan motivasi belajar pada pencapaiaan hasil belajar fisika peserta didik pada kelas XI MIA SMAN 1 Malunda.

Pada hipotesis ke empat efek interaksi dengan sumber variansi strategi pembelajaran dan motivasi belajar menghasilkan $F_{\text {hitung }}=6,67$ dan $F_{\text {tabel }}=4,11$ $\left(\mathrm{F}_{\text {hitung }}<\mathrm{F}_{\text {tabel }}\right) . \mathrm{H}_{0}$ ditolak. Artinya, terdapat interaksi antara strategi pembelajaran dan motivasi belajar pada pencapaiaan hasil belajar fisika peserta didik kelas XI MIA SMAN 1 Malunda.

\section{KESIMPULAN}

1. Terdapat perbedaan hasil belajar Fisika peserta didik yang diajar dengan menggunakan strategi pembelajaran $A R C S$ dan pembelajaran konvensional pada kelas XI MIA SMA Negeri 1 Malunda tahun ajaran 2016/2017.

2. Untuk Motivasi belajar tinggi, terdapat perbedaan hasil amtara belajar Fisika peserta didik yang diajar dengan strategi pembelajaran $A R C S$ dan pembelajaran konvensional. Rarata skor hasil belajar Fisika pada motivasi belajar tinggi untuk kelompok eksperimen lebih tinggi dari kelompok kontrol. Sehingga strategi pembelajaran ARCS lebih unggul dari pembelajaran konvensional untuk motivasi berprestasi tinggi pada kelas XI MIA SMA Negeri 1 Malunda tahun ajaran 2016/2017.

3. Untuk Motivasi belajar rendah, terdapat perbedaan hasil belajar Fisika peserta didik yang diajar dengan strategi pembelajaran $A R C S$ dan pembelajaran konvensional. Rerata skor hasil belajar Fisika pada motivasi belajar rendah untuk kelompok eksperimen lebih tinggi dari kelompok kontrol. Tetapi strategi pembelajaran ARCS tidak lebih unggul dari pembelajaran konvensional untuk motivasi berprestasi rendah pada kelas XI MIA SMA Negeri 1 Malunda tahun ajaran 2016/2017.

4. Terdapat interaksi antara strategi pembelajaran ARCS dan motivasi belajar Fisika terhadap hasil belajar Fisika peserta didik kelas XI MIA SMA Negeri 1 Malunda tahun ajaran 2016/2017. 


\section{SARAN}

Berdasarkan hasil penelitian yang diperoleh, maka disarankan kepada peneliti selanjutnya untuk meneliti penerapan strategi ARCS ditinjau dari : (1) Rasa percaya diri peserta didik; (2) Minat belajar fisika peserta didik; (3) Kemampuan bekerja sama dalam kelompok.

\section{DAFTAR PUSTAKA}

Anderson, Lorin \& krathwol. (2001). A Taxonomy for Learning, Teaching, and Assesing: A Revision of Bloom's Taxonomy of Educational Objectives (edisi terjemahan). Yogyakarta: Pustaka Pelajar.

Emzir. (2007). Metode penelitian kualitatif \& kuantitatif. Jakarta: Raja Grafindo Persada.

Keller. (1987). Development and Use of the ARCS Model Of Instructional Design. Jurnal of Instructional Development.

Nguyen Chi, (2008). Student Motivation and Learning. a 2-year faculty professional development program conducted by the Center for Teaching Excellence : Journal.

Palupi, Retno. Hubungan Antara Motivasi Belajar Dan Persepsi Siswa Terhadap Kinerja Guru Dalam Mengelola Kegiatan Belajar Dengan Hasil Belajar Ipa Siswa Kelas Viii Di Smpn N 1 Pacitan. Jurnal Teknologi Pendidikan Dan Pembelajaran. Vol.2, No.2, Edisi April 2014. ISSN: 2354-6441

Sardiman. (2008). Interaksi \& Motivasi Belajar Mengajar. Jakarta: PT Raja Grafindo persada

Uno, Hamzah B. (2008). Perencanaan Pembelajaran. Jakarta: Bumi Aksara

Wena M. 2010. Strategi Pembelajaran Inovatif Kontemporer. Jakarta : Bumi Aksara 